\title{
Strategi Penetapan Harga Jual Produk Melalui Perhitungan Cost of Goods Manufacture Menggunakan Process Costing Method
}

\author{
Popon Rabia Adawia ${ }^{1}$ \\ Fakultas Tehnik dan Infomatika \\ Universitas Bina Sarana Informatika, \\ Indonesia
}

\author{
Aprilia Puspasari ${ }^{2}$ \\ Fakultas Tehnik dan Infomatika \\ Universitas Bina Sarana Informatika, \\ Indonesia
}

\begin{abstract}
Surel : popon.pra@bsi.ac.id
ABSTRAK

Penelitian ini bertujuan untuk membantu UMKM Produk Sepatu didalam melakukan perhitungan Cost of Goods Manufacture (COGM) dengan tepat menggunakan process costing method sebagai strategi untuk menetapkan harga jual sepatu yang berdaya saing sehingga diharapkan usaha dapat terus berlanjut. Penelitian dilakukan di salah satu UMKM Produk Sepatu yaitu Amira Collection yang berlokasi di Karawang Timur. Metode deskriptif komparatif digunakan untuk mendeskripsikan biaya produksi yang terjadi dalam proses produksi meliputi biaya untuk membeli bahan baku, bahan penolong, biaya tenaga kerja dan biaya overhead pabrik. Hasil perhitungan COGM menunjukkan adanya varians (selisih) antara sistem perhitungan COGM perusahaan dengan sistem perhitungan COGM menggunakan process costing method dimana hasil perhitungan COGM perusahaan lebih rendah.
\end{abstract}

Kata Kunci: Harga Pokok Proses; Harga Pokok Produksi; Biaya Produksi; Harga Jual.

\section{Strategies For Determining The Selling Price Of Products By Calculating The Cost of Goods Manufacture Using The Process Costing Method}

\section{ABSTRACT}

This study aims to help SMEs for shoe products in calculating the Cost of Goods Manufacture (COGM) appropriately using the process costing method as a strategy to determine the selling price of competitive shoes so that it is hoped that the business can continue. The research was conducted at one of the MSME Shoe Products, namely the Amira Collection, which is located in East Karawang. The comparative descriptive method is used to describe the production costs that occur in the production process including costs to buy raw materials, auxiliary materials, labor costs and factory overhead costs. The COGM calculation results show the variance (difference) between the company's COGM calculation system and the COGM calculation system using the process costing method where the company's COGM calculation results are lower.

Keywords: $\quad$ Process Cost; Cost Of Goods Sold; Production Cost; Selling Price.

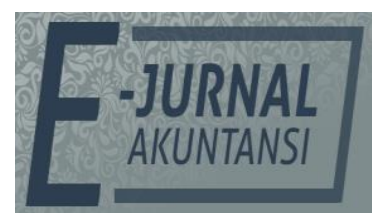

e-ISSN 2302-8556

Vol. 31 No. 5

Denpasar, Mei 2021

Hal. 1289-1302

DOI:

10.24843/EJA.2021.v31.i05.p16

PENGUTIPAN

Adawia, P.R., \& Puspasari, A. (2021). Strategi Penetapan

Harga Jual Produk Melalui

Perhitungan Cost of Goods Manufacture Menggunakan

Process Costing Method. EJurnal Akuntansi, 31(5), 1289-

1302

RIWAYAT ARTIKEL:

Artikel Masuk:

13 Oktober 2020

Artikel Diterima:

24 Mei 2021

Artikel dapat diakses : https://ojs.unud.ac.id/index.php/Akuntansi/index 


\section{PENDAHULUAN}

Industri memiliki peran sangat penting didalam suatu pembangunan dan menjadi salah satu sektor dalam suatu negara yang diperhitungkan karena dapat menjamin kelangsungan suatu proses pembangunan baik jangka panjang maupun jangka pendek. Industri juga diharapkan dapat membantu pemerintah didalam peningkatan pendapatan per kapita negara. Perkembangan sektor industri kian pesat setiap tahunnya ditandai dengan semakin banyaknya bermunculan usaha-usaha industri mulai dari skala mikro, kecil sampai menengah (UMKM). Di Indonesia keberadaan UMKM sangat membantu pertumbuhan ekonomi. Selain menggerakan roda perekonomian, UMKM juga menciptakan lapangan pekerjaan sehingga mengurangi jumlah pengangguran di Indonesia. Sebagaimana disampaikan oleh Rudjito bahwa Usaha Mikro Kecil dan Menengah (UMKM) adalah usaha yang mempunyai peranan penting dalam perekonomian Negara Indonesia, baik dari sisi lapangan kerja yang tercipta maupun dari sisi jumlah usahanya (Hamidah Q R, Pambudi A T, Mujahidah, 2019). UMKM saat ini menduduki posisi yang sangat penting didalam perekonomian negara khususnya pembangunan bidang ekonomi dan pembangunan sosial (Oteniya, A M, Sadiku, M N O, and Musa, 2019).

Saat ini kondisi dunia masih dilanda pandemi COVID-19 termasuk negara Indonesia. Dampak yang ditimbulkan dari pandemi sangat mempengaruhi aktifitas UMKM yang tengah bergeliat didalam membantu peningkatan pertumbuhan ekonomi. Faktanya pertumbuhan ekonomi di Indonesia pada saat ini kian memburuk dan perekonomian Indonesia sudah masuk dalam kategori resesi (Soleha, 2020). Banyaknya UMKM yang terpaksa harus tutup usaha atau tidak beroperasi lagi dikarenakan perusahaan sudah tidak mampu lagi menanggung biaya produksi. Pandemi COVID-19 menyebabkan profit usaha menurun secara signifikan akibat biaya produksi tetap atau bahkan meningkat sementara penjualan menurun. Biaya usaha yang mengalami peningkatan selama pandemi yaitu bahan baku, transportasi, tenaga kerja, dan biaya lain-lain. Berdasarkan hasil survey Pusat Penelitian Ekonomi LIPI ditemukan selama pandemi, 94,69\% usaha mengalami penurunan penjualan. Berdasarkan skala usaha, penurunan penjualan lebih dari $75 \%$ dialami oleh $49,01 \%$ usaha ultramikro, 43,3\% usaha mikro, 40\% usaha kecil, dan 45,83\% usaha menengah (Pusat Penelitian Ekonomi LIPI, 2020).

Menyikapi situasi pandemi covid-19 UMKM harus memiliki perencanaan yang cukup matang khususnya terkait dengan perencanaan strategi meningkatkan penjualan, pengalokasian dan perhitungan biaya produksi yang tepat. Berbagai upaya akan dilakukan dengan harapan usaha dapat terus berkembang secara berkesinambungan (sustainable) dan terus menerus menghasilkan keuntungan yang sebesar-besarnya. Walaupun keuntungan sebesar- besarnya bukan merupakan tujuan utama dari suatu usaha namun manajemen perusahaan akan tetap mengoptimalkan berbagai cara untuk meningkatkan nilai perusahaan. Meningkatkan nilai perusahaan dan mempertahankan agar bisnis dapat terus berjalan seperti yang diharapkan bukanlah hal yang mudah. Persaingan berupa kualitas produk, pangsa pasar, distribusi dan lain sebagainya terus saja terjadi. Untuk itu berbagai upaya akan terus dilakukan agar tetap dapat bersaing dalam kondisi apapun. Salah satu 
yang menjadi perhatian khusus bagi industri adalah tetap melakukan produksi dan menciptakan produk dengan kualitas terbaik namun harga jualnya dapat dijangkau oleh konsumen. Harga yang dapat dijangkau merupakan faktor penting dan menjadi perhatian khusus dimasa pandemi ini karena kemampuan daya beli masyarakat sangat terbatas.

Biaya produksi dibutuhkan untuk memproduksi barang. Biaya produksi adalah biaya - biaya yang dianggap melekat pada produk, meliputi biaya, baik langsung maupun tidak langsung dapat diidentifikasikan dengan kegiatan pengolahan bahan baku menjadi produk jadi (Harnanto, 2017). Biaya-biaya produksi menjadi dasar untuk perhitungan harga pokok produksi/cost of goods manufacture (COGM). COGM yaitu memperhitungkan jumlah biaya barang yang diselesaikan selama periode berjalan (Hansen, 2019). Sedangkan Mulyadi berpendapat bahwa COGM adalah sejumlah biaya yang terjadi untuk mengolah bahan baku menjadi produk jadi yang siap untuk dijual (Mulyadi, 2016). Perhitungan COGM harus tepat dan benar karena perhitungan yang kurang tepat menyebabkan penentuan harga jual produk juga menjadi kurang tepat pula. Hasil perhitungan COGM yang tinggi karena kesalahan didalam perhitungan akan menyebabkan harga jual menjadi tinggi. Konsumen akan kesulitan didalam daya beli dan mereka akan beralih kepada produk lain yang sejenis dengan kualitas yang sama namun memiliki harga yang lebih murah. Hal ini menyebabkan penjualan mengalami penurunan dan kerugian tidak dapat dihindari. Begitupula sebaliknya (Elena, 2018).

Menentukan COGM dengan tepat dan teliti merupakan salah satu tujuan dari akuntansi biaya. Menurut (Sujarweni, 2015), akuntansi biaya adalah informasi tentang biaya produksi untuk kepentingan kegiatan manajemen perusahaan indutsri yang meliputi, biaya bahan baku, biaya tenaga kerja langsung, biaya overhead pabrik, penyimpanan dan penjualan produk jadi. Didalam akuntansi biaya ada 2 (dua) cara produksi yang umumnya dilakukan oleh perusahaan dan hal ini sangat erat kaitannya dengan pengumpulan biaya produksi yaitu produksi yang dilakukan berdasarkan pesanan dan produksi yang dilakukan secara massa/proses. Untuk perusahaan yang melakukan produksi berdasarkan pesanan maka pengumpulan harga pokok produksinya dengan menggunakan metode harga pokok pesanan (job order costing). Sedangkan produksi yang dilakukan secara massa/proses maka pengumpulan harga pokok produksinya dengan menggunakan metode harga pokok proses (process costing) (Handayani, Winarni, 2020).

Perhitungan COGM yang tidak tepat akan menyebabkan kerugian bagi perusahaan (M. W. Dewi \& Muryati, 2017). Nilai COGM yang tinggi akibat perhitungan yang tidak tepat menyebabkan harga jual menjadi tinggi. Harga yang tinggi menyebabkan konsumen kesulitan didalam daya beli, sehingga mereka akan beralih ke perusahaan pesaing yang menjual barang, tentunya dengan harga terjangkau tetapi dengan kualitas produk yang sama. Penjualan semakin lama semakin menurun dan tidak dapat dihindari timbulnya kerugian. Begitupula dengan harga jual yang terlalu rendah yang disebabkan kurang tepat didalam perhitungan COGM sehingga menyebabkan laba menurun. Hal ini menjadi penting karena manajer membuat banyak keputusan melalui biaya produksi, ketepatan dalam perhitungan menjadi hal yang penting karena 
kesalahan kecil dapat berpengaruh besar pada laba perusahaan (Stoenoiu \& Cristea, 2018). Walaupun terkadang kualitas lebih unggul dari harga tetapi tetap dapat dilihat bahwa harga memegang peranan penting didalam keputusan pembelian suatu barang, sebagaimana hasil penelitian yang telah dilakukan oleh (Zulaicha, 2016).

Harga sangat penting dalam kelangsungan bisnis karena harga berpengaruh terhadap laba usaha dan posisi dari keuangan perusahaan (Tjiptono, 2016). Jenis strategi penetapan harga yang akan dipilih oleh UMKM akan bergantung pada tujuan yang ingin dicapai oleh strategi penetapan harga tersebut. Harga jual atau pricing merupakan suatu sistem manajemen perusahaan yang digunakan untuk menentukan harga dasar yang tepat bagi suatu barang atau jasa dan termasuk didalam harga jual adalah strategi yang menyangkut potongan harga, pembayaran ongkos angkut dan berbagai variabel yang bersangkutan (Kotler, 2016). Penetapan harga jual merupakan salah satu dari tujuan perhitungan COGM. Sebagaimana diungkapkan Mulyadi bahwa tujuan dari perhitungan COGM adalah menentukan harga jual produk, memantau realisasi biaya produksi, menghitung laba atau rugi bruto periodik tertentu, menentukan harga pokok persediaan produk jadi dan produk dalam proses yang disajikan dalam neraca (Mulyadi, 2016). Ada tiga tujuan dari penetapan harga jual yaitu : Profit oriented, Sales oriented dan Status-quo oriented. Profit oriented dimana perusahaan menetapkan harga dengan memaksimalkan keuntungan saat ini. Dalam upaya ini mereka mengevaluasi permintaan dan biaya yang menyertai harga alternatif dan memilih harga yang akan memaksimalkan keuntungan, pendapatan, atau tingkat pengembalian investasi. Sales oriented dinyatakan dalam volume penjualan atau pangsa pasar sebagai motivasi untuk menciptakan pertumbuhan penjualan atau untuk mempertahankan tingkat penjualan saat ini. Sedangkan status-quo oriented adalah penentuan harga jual dengan sasaran taktis yang mendorong persaingan pada faktor-faktor selain harga agar tetap kompetitif atau untuk menghindari perselisihan harga dengan pesaing mereka (Michael Colin Cant, Jan Wiid, 2016).

Salah satu UMKM yang tengah mempertahankan usahanya di masa pandemi COVID-19 adalah UMKM Amira Collection yang terdapat di daerah Karawang, Jawa Barat dan bergerak dalam industri pembuatan sepatu. Perusahaan memproduksi secara masal tujuannya adalah untuk persediaan sehingga metode untuk perhitungan harga pokoknya menggunakan process costing. Process Costing adalah metode perhitungan harga pokok produk berdasarkan biaya yang diproduksi pada suatu periode dibagi unit produksi (Sujarweni, 2015). Semakin banyak peminat sepatu koleksinya maka tingkat persaingan pun tidak dapat dihindari. UMKM harus berupaya melakukan strategi dengan menyajikan harga jual yang terjangkau namun dengan kualitas terbaik. Agar pertumbuhan usaha meningkat maka perlu ditunjang dengan kualitas sumber daya manusia (SDM) yang cakap dan handal. Kualitas SDM yang rendah dapat menyebabkan keberadaan UMKM lambat laun menunjukkan kinerja yang semakin menurun. Dimasa pandemi ini Amira Collection harus lebih cermat untuk mempersiapkan SDM agar dapat tetap mempertahankan usahanya, termasuk menyiapkan kemampuan SDM didalam pengalokasian dan perhitungan COGM dengan benar dan tepat. Karena faktanya banyak UMKM 
yang dalam perhitungan COGM hanya melakukan perhitungan berdasarkan estimasi/perkiraan dan tidak berdasarkan penerapan akuntansi biaya yang tepat. Untuk itu hal terpenting adalah bagaimana UMKM dapat melakukan perhitungan COGM dengan tepat, akurat dan rinci sehingga dapat diperoleh penetapan harga untuk penjualan yang bersaing/kompetitif dengan tujuan memperoleh laba sebesar-besarnya sehingga kinerja perusahaan dapat terus meningkat.

Penelitian-penelitian terdahulu mengenai perhitungan COGM dalam kaitannya dengan penetapan harga untuk penjualan sudah banyak dilakukan namun hasilnya belum konsisten. Penelitian-penelitian terdahulu antara lain (Komara, B \& Sudarma, 2016) dalam penelitiannya yang berjudul Analisis Penentuan Harga Pokok Produksi dengan Metode Full Costing sebagai dasar Penetapan Harga Jual. Hasil dari penelitian ini menyatakan bahwa harga pokok produksi tidak berpengaruh besar terhadap harga jual karena ada faktor lain yang mempengaruhi yaitu proporsi pemesanan dan presentase laba yang diinginkan. Semakin banyak kuantitas pesanan maka perhitungan harga pokok semakin tinggi sedangkan presentase laba semakin kecil. (Sukresna, 2017) juga melakukan penelitian dengan pembahasan mengenai perhitungan COGM. Hasil penelitiannya perusahaan menggunakan metode yang hampir mirip dengan metode full costing yaitu dengan membebankan semua biaya produksi yang dikeluarkan untuk menghasilkan produk diantaranya biaya bahan baku, biaya tenaga kerja, biaya bahan penolong, biaya overhead pabrik, biaya pasupati dan biaya keemasan. Setelah semua biaya produksi tersebut dihitung, kemudian ditentukan COGM lalu ditetapkanlah harga jual dengan mempertimbangkan margin laba yang diinginkan, PPN dan adanya produk yg rusak dalam produksi. Penelitian lainnya juga dilakukan (M. W. Dewi \& Muryati, 2017) dalam penelitiannya didalam menganalisa pengaruh biaya produksi menggunakan metode pemesanan terhadap harga jual produk pada PT. Aneka Printing Indonesia in Sukohardjo. Hasil penelitian menunjukkan bahwa perhitungan COGM berdasarkan hasil analisis dengan menggunakan metode full costing lebih besar daripada perhitungan COGM perusahaan.

Perbedaan penelitian ini dengan penelitian-penelitian terdahulu adalah penelitian ini disajikan dengan rinci bagaimana UMKM melakukan pengalokasian biaya produksi dan perhitungan COGM dengan tepat dan benar berdasarkan process costing dengan menambahkan unit equivalen kedalam perhitungan dan mempertimbangkan unsur produk yang rusak didalam perhitungan. Faktanya banyak UMKM yang melakukan pengalokasian dan perhitungan COGM dengan mengabaikan unsur unit equivalen dan produk yang rusak. Harapannya dari penelitian ini dapat diperoleh hasil perhitungan COGM yang tepat dan benar sebagai acuan untuk penetapan harga jual sehingga keuntungan perusahaan dapat terus meningkat dan perusahaan dapat mempertahankan usahanya dimasa pandemi ini.

\section{METODE PENELITIAN}

Sektor industri UMKM pada umumnya jarang melakukan pencatatan akuntansi secara lengkap dan menggunakan sistem akuntansi yang baik terutama terkait dengan biaya produksi yang dikeluarkan per unit barang, termasuk Amira 
Collection belum menerapkan perhitungan COGM dengan menggunakan kaidah akuntansi biaya yang tepat. Selama ini perusahaan melakukan perhitungan COGM berdasarkan estimasi atau perkiraan. Sangat berbeda dengan usaha skala menengah keatas yang dalam pencatatan akuntansinya sudah menggunakan suatu sistem akuntansi yang baik sehingga perhitungan COGM dapat dengan mudah, tepat dan benar dilakukan. Untuk itu penelitian ini dilakukan untuk mengidentifikasi mengenai biaya-biaya produksi yang digunakan didalam produksi pembuatan sepatu kemudian melakukan perhitungan COGM tepat dengan menggunakan kaidah akuntansi biaya yaitu metode process costing sehingga hasil perhitungan tersebut dapat berguna didalam penentuan harga jual yang tepat sebagai suatu strategi bagi perusahaan agar usaha dapat tetap berlanjut.

Penelitian pada UMKM Amira collection ini mengambil salah satu jenis produksi yaitu jenis pantopel. Banyak data-data digunakan untuk penelitian ini antara lain data utama/primer meliputi hasil interview bersama pemilik perusahaan dan beberapa orang karyawan. Observasi secara langsung kelapangan juga dilakukan guna melihat proses produksi dan mengidentifikasi biaya produksi apa saja yang timbul dari proses produksi tersebut. Sedangkan untuk data sekunder meliputi studi dokumentasi dengan mempelajari data-data perusahaan, dokumen/laporan biaya produksi milik perusahaan dan studi kepustakaan beserta kajian literature lain yang relevan didalam penelitian ini.

Metode penelitian deskriptif komparatif digunakan untuk menggambarkan biaya produksi yang timbul pada suatu proses produksi terdiri dari biaya-biaya untuk bahan baku langsung/bahan penolong, biaya untuk tenaga kerja langsung dan biaya untuk overhead pabrik untuk kemudian dihitung COGM-nya. Metode penelitian komparatif adalah suatu penelitian yang dilakukan dengan membandingkan antara variable satu dengan lainnya (Sugiyono, 2017). COGM disajikan dengan 2 metode, pertama berdasarkan perhitungan yang selama ini diterapkan perusahaan dan kedua dihitung berdasarkan metode process costing. Hasil perhitungan tersebut dibandingkan kemudian dianalisa sebagai strategi penentuan harga jual.

\section{HASIL DAN PEMBAHASAN}

Amira Collection melakukan produksi pembuatan sepatu dan sandal baik untuk laki-laki dan wanita baik dewasa maupun anak-anak. Banyak tipe sepatu dan sandal yang dihasilkan salah satunya adalah tipe sepatu jenis pantopel untuk pria. Sepatu jenis ini diproduksi setiap bulannya oleh perusahaan sebanyak 10 kodi atau 200 pasang. Dasar produksi untuk persediaan digudang kemudian dijual secara rutin kepada para pelanggannya. Kapasitas produksi sepatu tipe ini adalah $15 \%$ dari semua kapasitas produksi sepatu dan sendal. Perincian biaya produksi dan perhitungan COGM untuk memproduksi sepatu pantopel ini ratarata per bulan disajikan berdasarkan metode process costing sebagai berikut. 
Biaya bahan baku. Bahan baku terbagi menjadi dua yaitu bahan baku langsung dan tidak langsung. Bahan baku langsung merupakan bahan-bahan yang dapat secara mudah dan akurat ditelusuri ke produk jadi dan siap jual (Putra, 2018). Perincian biaya bahan baku yang digunakan Amira Collection didalam produksi sepatu pantopel disajikan dalam Tabel 1.

\section{Tabel 1. Biaya Bahan-Bahan Baku (BBB)}

\begin{tabular}{lr}
\hline Jenis Bahan Baku & Biaya (Rp) \\
\hline Bahan Newbook AC & 956.000 \\
Bahan AC Harmony & 475.000 \\
Pur CE & 330.000 \\
Tekson $1,3 \mathrm{~mm}$ & 250.000 \\
Sol YY & 364.000 \\
Tamsin Iron 14 & 225.000 \\
Total Biaya Bahan Baku & 2.600 .000
\end{tabular}

Sumber: Data Penelitian, 2020

Bahan pembantu/penolong adalah bahan-bahan yang merupakan bagian dari produk yang telah selesai dan nilainya relative kecil jika dibandingkan dengan beban pokok produksi tersebut (Wulandari, 2016). Perincian biaya bahan penolong yang digunakan Amira Collection didalam produksi sepatu pantopel disajikan dalam Tabel 2.

Tabel 2. Biaya Bahan Penolong (BBP)

\begin{tabular}{clccr}
\hline No & Bahan Pembantu & Jumlah(kodi) & $@$ Rp & Total (Rp) \\
\hline 1 & Ujung keras & 10 & 5500 & 75.000 \\
2 & Embos Merk & 10 & 2500 & 35.000 \\
3 & PC & 10 & 9200 & 112.000 \\
4 & Qbon PU & 10 & 8300 & 87.500 \\
5 & Qbon KNG & 10 & 8200 & 82.000 \\
6 & Lateks & 10 & 1000 & 18.750 \\
7 & Spon 11/2 ml & 10 & 5700 & 68.000 \\
8 & Sewing thread & 10 & 1255 & 17.550 \\
9 & Cardboard & 10 & 7500 & 82.500 \\
10 & Accessories & 10 & 4500 & 45.000 \\
11 & Peralatan & & & 300.000 \\
Total Biaya Bahan Penolong & & & 923.300 \\
\hline
\end{tabular}

Sumber: Data Penelitian, 2020

Biaya tenaga kerja langsung adalah tenaga kerja yang secara fisik langsung terlibat dengan pembuatan produk. Biaya yang timbul karenanya merupakan biaya tenaga kerja utama yang dapat ditelusuri melekatnya pada produk. Besarnya biaya tenaga kerja utama yang dapat dihitung berdasarkan jam kerja, hari kerja, dan satuan produk. Biaya tenaga kerja langsung pada umumnya dihitung dengan berdasarkan biaya yang benar-benar terpakai dalam produksi atau biaya yang sesungguhnya terjadi dan digunakan untuk menghasilkan barang. Contoh dari biaya tenaga kerja langsung adalah biaya gaji dari karyawan perusahaan. (Budiman, Ilat, 2019).

Dalam penelitian ini untuk penggajian berlaku sistem upah yaitu tenaga kerja dibayar berdasarkan jumlah sepatu yang dihasilkan sebagaimana disajikan 
dalam rincian di Tabel 3.

Tabe1 3. Biaya Tenaga Kerja Langsung (BTKL)

\begin{tabular}{lcrr}
\hline Tipe Pekerjaan & Jumlah (Kodi) & Upah/kodi (Rp) & Total (Rp) \\
\hline Disainer & - & - & 550.000 \\
Tukang atas & 10 & 55.000 & 550.000 \\
Tukang bawah & 10 & 35.000 & 350.000 \\
Tukang sol & 10 & 4.500 & 45.000 \\
Tukang bensol & 10 & 10.000 & 100.000 \\
Tukang penyelesaian & 10 & 8.500 & 85.000 \\
Uang makan & 10 & 45.000 & 450.000 \\
Total Biaya Tenaga Kerja Langsung & & & 2.130 .000 \\
\hline
\end{tabular}

Sumber: Data Penelitian, 2020

Biaya overhead adalah biaya-biaya bahan tak langsung, buruh tak langsung dan biaya-biaya pabrik lainnya yang tidak secara mudah diidentifikasi atau di bebankan langsung pada suatu pekerjaan, hasil produksi/tujuan biaya akhir (Dalimunthe, 2018). Dalam process costing, untuk biaya overhead pabrik terdiri dari biaya-biaya untuk bahan pembantu atau penolong, biaya untuk depresiasi/penyusutan aktiva pabrik, biaya untuk sewa gedung pabrik dan biaya overhead lain-lain. Biaya Listrik, dialokasikan untuk sepatu flathshoes $15 \%$ yaitu Rp $1.043 .300 \times 15 \%=\operatorname{Rp} 156.500 /$ bulan. Biaya Telephone, dialokasi untuk pantopel 15\% yaitu Rp 600.000 x 15\% = Rp 90.000/bulan.

Biaya Pemeliharaan Mesin (mesin PON dan mesin jahit) dan Kendaraan meliputi biaya perawatan ditambah dengan biaya perbaikan serta pembelian mesin dan suku cadang kendaraan jika mengalami kerusakan. Dialokasikan untuk pantopel yaitu Rp 875,000 x 15\% = Rp 131.250/month. Perincian Biaya Pemeliharaan Mesin dan Kendaraan disajikan pada Tabel 4.

Tabel 4. Biaya Pemeliharaan

\begin{tabular}{rlr}
\hline No & Jenis & Biaya (Rp) \\
\hline 1 & Mesin Jahit & 300.000 \\
2 & Mesin PON & 175.000 \\
3 & Motor (2 units) & 400.000 \\
& Total & 875.000 \\
\hline
\end{tabular}

Sumber: Data Penelitian, 2020

Setiap penggunaan mesin dan penggunaan kendaraan untuk aktivitas produksi, mengalami pengurangan nilai asset tersebut yang disebut penyusutan. Akibat yang ditimbulkan dari nilai yang menyusut/penyusutan dari mesin dan kendaraan tersebut menyebabkan timbulnya biaya yang dikenal dengan depreciation cost atau biaya penyusutan. Cara menghitung besarnya nilai yang menyusut tersebut menggunakan dasar economic value atau yang lebih dikenal dengan sebutan straight line method (Kieso, D.E., 2018).

Biaya Penyusutan $=\underline{(\text { Harga Perolehan }- \text { Nilai Residu })}$

Biaya Penyusutan Mesin Jahit (Rp 7.500.000-Rp 1.500,000): $5=R p$ 1.200.000/tahun. Rp 1.200.000:12 = Rp 100.000/bulan. Dialokasikan untuk pantopel sebesar $\operatorname{Rp} 100.000 \times 15 \%=R p$ 15.000. Biaya Penyusutan Mesin PON $(\operatorname{Rp~3.000.000-Rp~1.000.000):~} 5=R$. 400.000/tahun. $\operatorname{Rp} 400.000: 12=R p$ 
33.000/bulan. Dialokasikan untuk pantopel sebesar $\operatorname{Rp} 33.000 \times 15 \%=\operatorname{Rp} 4.950$. Biaya Penyusutan Motor (Rp 30.000.000-Rp 6.000.000): $7=\operatorname{Rp~3.428.500/tahun.~}$ Rp 3.428.500: $12=\operatorname{Rp} 285.700 /$ bulan. Dialokasikan untuk pantopel sebesar Rp $285.700 \times 15 \%=\operatorname{Rp} 42.855$.

Tabel 5. Biaya Penyusutan Mesin dan Kendaraan

\begin{tabular}{cc}
\hline Tipe & Jumlah (Rp) \\
\hline Mesin Jahit & 15.000 \\
Mesin PON & 4.950 \\
Motor & 42.855 \\
Total & 62.805 \\
\hline
\end{tabular}

Sumber: Data Penelitian, 2020

Berdasarkan hasil perhitungan Tabel 5, diperoleh biaya penyusutan untuk mesin jahit yaitu Rp 15.000,-/ bulan, untuk mesin PON sebesar Rp 4.950,/bulan dan biaya penyusutan untuk kendaraan motor sebesar Rp 42.855,-/bulan. Sehingga diperoleh total biaya penyusutan mesin dan kendaraan sebesar $\mathrm{Rp}$ 62.805/bulan. Biaya Pemeliharaan Gedung Rp 250.000/bulan. Dialokasikan untuk pantopel sebesar: Rp $250.000 \times 15 \%=R p$ 37.500. Biaya Penyusutan Gedung $(\operatorname{Rp~150.000.000-Rp~30.000.000):~} 20=\operatorname{Rp} 6.000 .000 /$ tahun. Rp 6.000.000: $12=R p$ $500.000 /$ bulan. Dialokasikan untuk pantopel sebesar Rp $500.000 \times 15 \%=R p$ 75.000 .

Tabel 6. Perhitungan Biaya Overhead Pabrik (BOP)

\begin{tabular}{lr}
\hline Biaya & Jumlah (Rp) \\
\hline Listrik & 156.500 \\
Telephone & 90.000 \\
Pemeliharaan mesin dan kendaraan & 131.250 \\
Penyusutan mesin dan kendaraan & 62.805 \\
Pemeliharaan gedung & 37.500 \\
Penyusutan gedung & 75.000 \\
Total Biaya Overhead Pabarik & 553.055 \\
\hline
\end{tabular}

Sumber: Data Penelitian, 2020

Berdasarkan perhitungan diperoleh biaya pemeliharaan gedung $\mathrm{Rp} 37.500$ dan biaya penyusutan gedung sebesar Rp 75.000,-. Perincian keseluruhan biaya overhead pabrik disajikan pada Tabel 6 .

Tabel 7. Perhitungan COGM Per Unit

\begin{tabular}{lccc}
\hline Elemen Biaya Produksi & Total Biaya $(\mathrm{Rp})$ & Unit equivalen & COGM (Rp) \\
\hline \multicolumn{1}{c}{$(1)$} & $(2)$ & $(3)$ & $(2):(3)$ \\
\hline Bahan baku & 2.600 .000 & 200 pasang & 13.000 \\
Bahan Penolong & 923.300 & 200 pasang & $4.616,5$ \\
Tenaga kerja & 2.130 .000 & 196 pasang & $10.867,3$ \\
Overhead & 553.055 & 194 pasang & $2.850,8$ \\
Total & 6.206 .355 & & $31.334,6$ \\
\hline
\end{tabular}

Sumber: Data Penelitian, 2020

Perusahaan memproduksi sepatu hanya dalam satu departemen. Dalam tahap pengelolaan ada beberapa produksi yang mengalami rusak sehingga tidak laku dijual. Adapun informasi data terkait produksi dan biaya adalah produk masuk proses sebanyak 200 pasang sepatu, dari jumlah tersebut 175 pasang sepatu telah selesai dan produk rusak sebanyak 5 pasang sepatu dan 20 masih 
dalam proses dengan tingkat penyelesaian (BBB 100\%, BP 100\%, BTKL 80\%, BOP $70 \%$ ). Perincian hasil perhitungan unit equivalen dan harga pokok/cogm per unit disajikan pada Tabel 7.

Unit equivalen merupakan jumlah perkiraan dari seluruh unit produksi yang dapat dihasilkan selama priode tertentu (Mulyadi, 2016). Untuk menghitung unit equivalen dapat menggunakan rumus sebagai berikut.

(Produk Jadi + Produk Rusak + (produk yang masih didalam proses $\mathrm{x} \%$ tingkat penyelesaian)

Biaya Bahan Baku

$$
\begin{aligned}
& =175+5+(100 \% \times 20)=200 \\
& =175+5+(100 \% \times 20)=200 \\
& =175+5+(80 \% \times 20)=196 \\
& =175+5+(70 \% \times 20)=194
\end{aligned}
$$

Biaya Overhead Pabrik

Dari hasil perhitungan, maka dibuatlah laporan biaya produksi sebagai

\begin{tabular}{|c|c|c|}
\hline \multicolumn{3}{|l|}{ Data Produksi } \\
\hline Data yang dimasukkan dlm proses & & 200 pasang \\
\hline $\begin{array}{l}\text { Produk yang ditransfer ke dalam } \\
\text { gudang }\end{array}$ & & 175 pasang \\
\hline Produk dalam proses & & 20 pasang \\
\hline Produk rusak & & 5 pasang \\
\hline Jumlah produk yang dihasilkan & & 200 pasang \\
\hline Biaya Produksi & Total (Rp) & COGM (Rp) \\
\hline BBB & 2.600 .000 & 13.000 \\
\hline $\mathrm{BP}$ & 923.300 & $4.616,5$ \\
\hline BTKL & 2.130 .000 & $10.867,3$ \\
\hline BOP & 553.055 & $2.850,8$ \\
\hline Total & 6.206.355 & 31.334,6/pasang \\
\hline \multicolumn{3}{|l|}{ Perhitungan Rincian Biaya } \\
\hline \multicolumn{3}{|c|}{ Harga Pokok Produk selesai ditransfer ke gudang (175 pasang @ } \\
\hline Harga Pokok Produk Rusak (5 pasang @ Rp 31.334,6) & & 156.673 \\
\hline \multicolumn{3}{|l|}{ Harga Pokok Produk belum selesai (in process) } \\
\hline BBB : $100 \%$ x 20 × Rp 13.000 & $\operatorname{Rp} 260.000$ & \\
\hline BP : $100 \% \times 20 \times \operatorname{Rp} 4.616,5$ & 92.330 & \\
\hline BTKL : $80 \%$ x $20 \times \operatorname{Rp} 10.867,3$ & $173.876,8$ & \\
\hline BOP : $70 \%$ x 20 x Rp 2.850,8 & $\underline{39.911,2}$ & \\
\hline Total Biaya Produksi rata-rata per bulan & & $\begin{array}{cr}R p & 566.118 \\
\operatorname{Rp} & 6.206 .355 \\
\text { (dibulatkan) }\end{array}$ \\
\hline
\end{tabular}
informasi untuk penentuan harga jual. Laporan hasil produksi disajikan pada Tabel 8.

Tabel 8. Laporan Harga Pokok Produksi "Pantopel" (Process Costing Method)

Sumber: Data Penelitian, 2020

Laporan biaya produksi ini menjadi informasi yang sangat bermanfaat bagi pihak intern perusahaan yaitu manajemen perusahaan. Dimana dengan informasi ini perusahaan dapat membuat strategi untuk penentuan harga jual. Informasi dari laporan biaya produksi ini akan dibandingkan dengan informasi perhitungan COGM yang dibuat oleh perusahaan setiap periodenya. Rincian perhitungan COGM yang disajikan oleh perusahaan setiap bulannya didalam 
membuat sepatu pantopel dalam Tabel 9, sebagai berikut.

Tabel 9. Laporan Cost of Goods Manufacture produk Pantopel Amira Collection

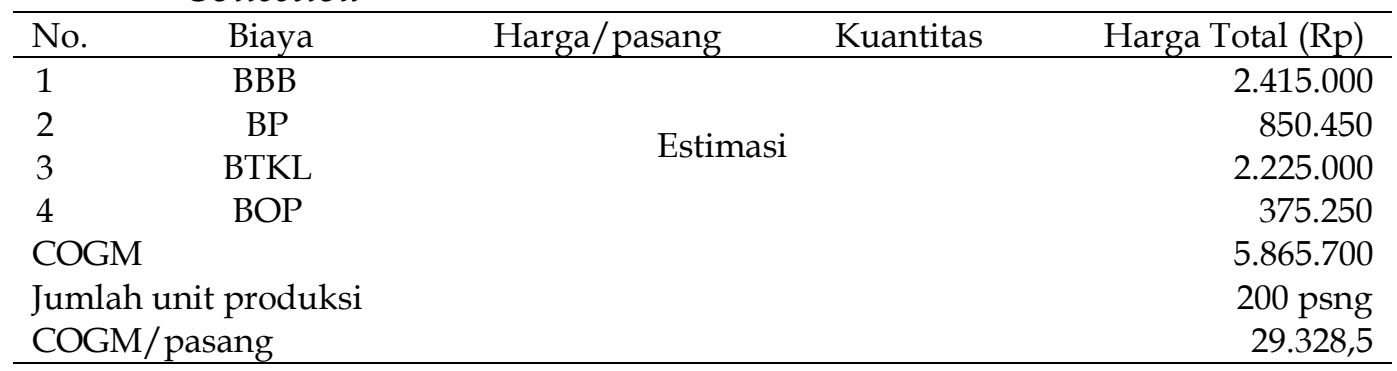

Sumber: Data Penelitian, 2020

Selanjutnya dilakukan analisis perbandingan perhitungan COGM. Dari hasil analisa yang telah dilakukan diperoleh suatu varians (selisih) antara hasil perhitungan COGM menggunakan process costing method dengan perhitungan COGM yang dibuat oleh perusahaan. Perbandingan perhitungan disajikan pada Tabel 10.

Tabel 10. Perbandingan Perhitungan COGM berdasarkan Process Costing dengan Perhitungan COGM Perusahaan rata-rata per bulan

\begin{tabular}{|c|c|c|c|c|}
\hline \multirow{2}{*}{$\begin{array}{c}\text { Elemen } \\
\text { Biaya }\end{array}$} & \multicolumn{2}{|c|}{ Perhitungan COGM (Rp) } & \multirow{2}{*}{$\begin{array}{r}\text { Selisih } \\
\text { (Rp) }\end{array}$} & \multirow[t]{2}{*}{ Keterangan } \\
\hline & $\begin{array}{c}\text { Amira } \\
\text { Collection }\end{array}$ & $\begin{array}{l}\text { Process } \\
\text { Costing }\end{array}$ & & \\
\hline BBB & 2.415 .000 & 2.600 .000 & 185.000 & $\begin{array}{l}\text { Perhitungan process } \\
\text { costing secara detail } \\
\text { mengalokasikan biaya } \\
\text { sesuai pemakaian }\end{array}$ \\
\hline $\mathrm{BP}$ & 850.450 & 923.300 & 72.850 & $\begin{array}{l}\text { Perhitungan process } \\
\text { costing secara detail } \\
\text { mengalokasikan biaya } \\
\text { sesuai pemakaian }\end{array}$ \\
\hline BTKL & 2.225 .000 & 2.130 .000 & 95.000 & $\begin{array}{l}\text { Perhitungan process } \\
\text { costing berdasarkan } \\
\text { persentase tingkat } \\
\text { penyelesaian pekerjaan }\end{array}$ \\
\hline BOP & 375.250 & 553.055 & 177.805 & $\begin{array}{l}\text { Perhitungan process } \\
\text { costing secara detail } \\
\text { mengalokasikan biaya } \\
\text { sesuai pemakaian adanya } \\
\text { perhitungan penyusutan }\end{array}$ \\
\hline COGM & 5.865 .700 & 6.206 .355 & 530.655 & \\
\hline $\begin{array}{c}\text { COGM/ } \\
\text { pasang }\end{array}$ & $29.328,5$ & $31.334,6$ & $2.006,1$ & \\
\hline
\end{tabular}

Sumber: Data Penelitian, 2020

Berdasarkan dokumen laporan biaya produksi rata-rata per bulan yang dibuat oleh perusahaan terdapat selisih angka perhitungan COGM. Process costing memperoleh perhitungan COGM sebesar Rp 6.206.355,- sehingga jika dibandingkan COGM berdasarkan perhitungan perusahaan maka akan diperoleh selisih sebesar Rp 2.006,1/pasang. Perbedaan ini disebabkan karena 
dalam perhitungan dengan menggunakan metode process costing secara detail dan rinci pengalokasian setiap biaya khususnya untuk pemakaian biaya untuk bahan baku sampai dengan biaya overhead pabrik. Didalam perhitungan COGM perusahaan mengabaikan pembebanan biaya penyusutan, biaya pemakaian perlengkapan dan penggunaan biaya overhead lainnya yang seharusnya tetap diperhitungkan walaupun nilainya tidak besar. Karena hal tersebut melekat pada produk yang dihasilkan.

Sebagai strategi untuk menentukan harga jual sepatu, perusahaan dapat menggunakan strategi profit oriented yaitu menggunakan persentasi laba yang diinginkan. COGM per unit menjadi dasar perhitungannya. Misalkan perusahaan ingin memperoleh keuntungan sebesar 60\% dari harga pokoknya maka harga jual sepatu pantopel tersebut adalah sebesar.

COGM (per pasang) : :Rp 31.334,6,-

Persentase laba yg diinginkan $(60 \%) \quad: \underline{R p ~ 18.800,76,-}$

Harga Jual

$: \underline{\operatorname{Rp~} 50.150,-(\text { dibulatkan) }}$

Harga jual ini bersifat bruto karena biasanya perusahaan akan menambahkannya dengan biaya lain yang sifatnya non produksi antara lain biaya-biaya untuk pemasaran produk dan biaya untuk administrasi. Sehingga dihasilkan harga jual produk dengan memperoleh keuntungan yang diharapkan.

Hasil penelitian ini senada dengan hasil penelitian yang dilakukan oleh (Dewi, 2017) yang mengatakan bahwa untuk perhitungan COGM menggunakan metode akuntansi biaya (full costing) memperoleh hasil lebih besar daripada perhitungan COGM perusahaan. Senada pula dengan penelitian yang dilakukan (Sukresna, 2017) yang menggunakan profit (margin laba) didalam penentuan harga jual.

Perhitungan COGM yang tepat dan teliti memberikan keputusan bagi manajemen didalam mengatur pricing strategy sehingga secara berkesinambungan perusahaan dapat memperoleh keuntungan maksimal yang diinginkan.

\section{SIMPULAN}

Dari pembahasan, dapat disimpulkan bahwa metode process costing digunakan oleh usaha industri yang melakukan produksi secara massa/proses. Khususnya dalam perhitungan COGM hendaknya perusahaan tidak mengabaikan unit equivalen dan tetap memperhitungkan adanya produk yang rusak. Dalam perhitungan COGM dengan menggunakan metode process costing dihasilkan harga per unit menjadi lebih tinggi dibandingkan dengan metode yang selama ini perusahaan terapkan hal ini karena adanya pengalokasian biaya produksi (biaya bahan baku, biaya tenaga kerja dan biaya overhead pabrik) tidak dilakukan secara rinci dan teliti. Beberapa biaya yang timbul dari produksi tidak dimasukkan kedalam perhitungan COGM. Walaupun berdasarkan metode process costing harga per unit menjadi lebih tinggi namun laba yang dihasilkan akan lebih maksimal dibandingkan dengan metode yang selama ini perusahaan terapkan dengan memperoleh laba yang sangat minim. Hasil pengalokasian biaya produksi dan perhitungan COGM secara rinci, tepat dan benar dapat memberikan informasi akhir berupa laporan harga pokok produksi yang sangat berguna bagi manajemen untuk pengambilan keputusan didalam penetapan 
harga jual. Bagi Amira Collection perhitungan COGM dengan menggunakan metode process costing ini sangat membantu untuk dapat tetap bertahan dimasa pandemi COVID-19 ini dengan perolehan laba yang semakin meningkat.

Metode process costing merupakan metode perhitungan COGM yang sangat penting. Process costing dapat dikatakan sebagai salah satu strategi yang dapat diterapkan oleh UMKM untuk dapat tetap mempertahankan usahanya di masa pandemi. Usaha yang stabil dan perolehan laba yang semakin meningkat menjadi tujuan dari penerapan metode ini.

Penelitian selanjutnya dapat dilakukan perhitungan COGM dengan menggunakan metode lainnya yang disesuaikan dengan jenis usaha dan produksi UMKM. Selain itu penelitian dapat dilakukan menggunakan jenis metode penelitian kuantitatif dengan mengukur hubungan dan pengaruh variable COGM dengan variable harga jual atau dapat digunakan variable lainnya. Penelitian dapat juga dilakukan dengan memperluas objek penelitian pada skala UMKM Nasional atau Internasional.

\section{REFERENSI}

Budiman, Ilat, M. (2019). Analisis Penentuan Biaya Produksi Dengan Menggunakan Metode Full Costing Untuk Menentukan Harga Jual Pada Pt. Blue Ocean Grace International. Jurnal Riset Akuntansi Going Concern, 14 No. 1, 122-129.

Dalimunthe, B. \& K.-K. (2018). Menghitung Biaya Overhead Pabrik Pada Usaha Tempahan Sepatu BaruS. Jurnal Niagawan, 7 No. 3, 185-191.

Dewi, M. D. M. (2017). An Analysis of Production Cost Effect With Order Price Method on Sales Pricing of Product at PT Anke Printing Indonesia in Sukoharjo. Peer Reviewed-International Journal of Economics, Business and Accounting Research (IJEBAR), 1(2).

Dewi, M. W., \& Muryati, M. (2017). An Analysis of Production Cost Effect With Order Price Method on Sales Pricing of Products at PT. Aneka Printing Indonesia in Sukoharjo. International Journal of Economics, Business and $\begin{array}{llll}\text { Accounting } \quad \text { Research } & \text { (IJEBAR), }\end{array}$ https://doi.org/10.29040/ijebar.v1i02.255

Elena, C. S. and C. C. (2018). Comparative analysis for estimating production costs. MATEC Web of Conferences 184, 04004 (2018) Annual Session of Scientific Papers IMT ORADEA 2018. https://doi.org/https://doi.org/10.1051/matecconf/201818404004

Hamidah Q R, Pambudi A T, Mujahidah, A. Z. (2019). The Development of Small and Medium Businesses (MSMEs) Based on Tecnology to Deal with The Industrial Revolution 4.0. 4th National Seminar on Educational Innovation (SNIP 2019), 345-349.

Handayani, Winarni, A. \& S. (2020). Analysis Of Production Cost Calculation Based On Order (Job Order Costing) In Rafi Jaya Mebel (Rjm) Suak Temenggung. Research In Accounting Journal, 1 No. 1, 187-195. http://journal.yrpipku.com/index.php/raj

Hansen, D. R. dan M. M. M. (2019). Akuntansi Manajerial (8th ed.). Salemba Empat.

Harnanto. (2017). Akuntansi Biaya. Andi bekerjasana dengan BPFE UGM. 
Kieso, D.E., et. al. (2018). Intermediate Accounting (IFRS editi). John Wiley and Sons, Inc.

Komara, B \& Sudarma, A. (2016). Analisis Penentuan Harga Pokok Produksi dengan Metode Full Costing sebagai dasar Penetapan Harga Jual. Jurnal Ilmia Ilmu Ekonomi, Vol.5 Edis(Universitas Muhammadiyah Sukabumi.).

Kotler, P. and G. A. (2016). Manajemen Pemasaran (14th ed.). Erlangga.

Michael Colin Cant, Jan Wiid, C. M. S. (2016). Key Factors Influencing Pricing Strategies For Small Business Enterprises (SMEs): Are They Important? The Journal of Applied Business Research - November/December 2016, Volume 32,(The Clute Institute), 1737-1750.

Mulyadi. (2016). Akuntansi Biaya (6th ed.). UPP STIM YKPN.

Oteniya, A M, Sadiku, M N O, and Musa, S. M. (2019). Small and Medium-Sized Enterprises. International Journal of Scientific and Research Publications, 9(12), $\begin{array}{lllll}\text { December } & 2019 & 279 & \text { ISSN } & \text { 2250-3153. }\end{array}$ http:/ /dx.doi.org/10.29322/IJSRP.9.12.2019.p9632

Pusat Penelitian Ekonomi LIPI. (2020). Survey Kinerja UMKM di Masa pandemi Covid-19. http://lipi.go.id/berita/survei-kinerja-umkm-di-masa-pandemicovid19/22071

Putra, I. M. (2018). Akuntansi Biaya (Pertama). QUADRANT.

Soleha, A. R. (2020). Kondisi UMKM Masa Pandemi COVID-19 Pada Pertumbuhan Ekonomi Krisis Serta Program Pemulihan Ekonomi Nasional. Ekombis, Vol 6, No. http://jurnal.utu.ac.id/ekombis/article/view/2881

Stoenoiu, C. E., \& Cristea, C. (2018). Comparative analysis for estimating production costs. MATEC Web of Conferences, 184, 1-6. https://doi.org/10.1051/matecconf/201818404004

Sugiyono. (2017). Metode Penelitian Kuantitatif, Kualitatif, RED. Alfabeta.

Sujarweni, V. W. (2015). Akuntansi Biaya. Pustaka Baru Press.

Sukresna, I. W. S. (2017). Analisis Penentuan Harga Pokok Produksi untuk menetapkan Harga Jual Produk Dupa Tridatu Pasupati Pada Kaori Group di Kecamatan Ubud, Kabupaten Gianyar. Jurnal Undishka, Vol. 8 No.

Tjiptono, F. (2016). Service, Quality \& satisfaction. Andi, Yogjakarta.

Wulandari, A. \& I. (2016). The Effect Of Production Cost To Net Profit; A Case Study Of Pt. Indorama Synthetics Tbk). Business And Managementstudies Journal, . VOL. 3 ., 54-64.

Zulaicha, S. dan R. I. (2016). Pengaruh Produk dan Harga Terhadap keputusan Pembelian Konsumen di Morning Bakery Batam. Inovbiz: Jurnal Inovasi Dan Bisnis, Vol. 4, No(Politeknik Negeri Batam), 125-136. 